\title{
Identification of Agricultural Activities and Soil Fertility in the Cultivation Area of Nuabosi Cassava
}

\author{
Charly Mutiara ${ }^{1 *}$ and Yovita Yasintha Bolly ${ }^{2}$ \\ ${ }^{1}$ Department of Agrotechnology, Faculty of Agriculture, Flores University, Indonesia; ${ }^{2}$ Department of \\ Agrotechnology, Faculty of Agriculture, Nusa Nipa University, Indonesia \\ *Corresponding author: charlyinter1988@gmail.com
}

\begin{abstract}
The low soil fertility is one of the causes of the reduction in cassava production in the Nuabosi area of Ende Regency. Therefore it is necessary to identify soil fertility and farmer activities on the land. This research used survey system by takes soil samples and farmers from ten fields in five villages, namely Ndetundora I, Ndetundora II, Ndetundora III, Embuteru and Randotonda. Determination of land were used purposive sampling method. Whereas farmer activity data is obtained by interviewing farmers whose land is used as land sampling. Variables observed were physical and chemical soil properties. The results of the analysis of agricultural activities can be described using existing theories. While the analysis results of the physical and chemical properties of the soil can be described using chemical criteria and soil fertility from the Bogor soil research center. The results of interviews and direct observations in the field showed that Nuabosi cassava farmers did not only plant cassava but also used conservative agricultural on their land. The physical properties of the soil analyzed showed that the soil was suitable for cassava plants. Based on soil fertility criteria, these lands have a limiting factor for C-Organic.
\end{abstract}

Keywords: farmer activity, Nuabosi, soil fertility

Cite this as: Mutiara, C. \& Bolly, Y. Y. (2019). Identification of Agricultural Activities and Soil Fertility in the Cultivation Area of Nuabosi Cassava. Caraka Tani: Journal of Sustainable Agriculture, 34(1), 22-30. doi: http://dx.doi.org/10.20961/carakatani.v34i1.25708

\section{INTRODUCTION}

The condition agricultural land is strongly associated with agricultural activities that take place on it. Some agricultural activities that generally carried out and affect soil fertility are soil management, fertilization, weeding, mulching and pesticide application. These activities can affect the physical and chemical properties of soil, crop production and surface runoff (Triyono, 2007; Lestari, 2009; Sarno, 2009; Dewanto et al., 2013; Andreawan et al., 2015; Muhammad et al., 2015). A similar opinion was expressed by Wahyuningtyas (2010) that often treated can accelerate the rate of soil erosion. The impacts of farmer activity above can reduce soil fertility.

Soil fertility is related to interactions between physical, chemical and biological properties of the soil. Good soil management can improve soil properties so that the soil fertility will increase. This soil fertility will then have a large influence on the productivity of plants that grow on it (Mulyanti et al., 2015). One type of plant that influences its productivity due to changes in soil fertility is Cassava (Manihot esculenta Crantz). Moreover, the productivity of cassava in Ende District is not stableyet. From the available data, it shows that although cassava harvested area has increased (240 ha in 2014 and 453 ha in 2016) but

\footnotetext{
* Received for publication November 30, 2018 Accepted after corrections February 27, 2019
} 
has decreased productivity which is $116.6 \mathrm{~kg} \mathrm{ha}^{-1}$ in 2014, $120 \mathrm{~kg} \mathrm{ha}^{-1}$ in 2015 and $35 \mathrm{~kg} \mathrm{ha}^{-1}$ in 2016 (Dinas Pertanian Kabupaten Ende, 2017). This decrease in productivity also occurs in Nuabosi cassava which is it known from the results of interviews with several farmers who cultivated the Nuabosi cassava.

Nuabosi cassava is one of the famous types of cassava from Ende Regency and cultivates in several villages in Ende District. The villages are Embuteru, Ndetundora I, Ndetundora II, Ndetundora III and Randotonda. Breeding of Nuabosi Cassava has been carried out in 2015 and registered by the Governor of East Nusa Tenggara Province on October 19, 2015. The name of the variety registered for cassava is Nuabosi with registration number 186/PVL/2015 (Pusat Perlindungan Varietas Tanaman dan Perizinan Pertanian, 2016). By registering Nuabosi cassava as a local variety, various efforts are needed to maintain its sustainability.

The sustainability of Nuabosi's cassava which is maintained strongly supports the creation of food security. Food security of a region can be improved by utilizing local food that is widely available in the region (Undang-Undang Nomor 18, 2012). Cassava can support food security because it contains high carbohydrates which can replace the dependence on rice (Susilawati et al., 2008; Masniah and Yusuf, 2013). Besides having a high carbohydrate, Nuabosi's cassava is also tolerant of leaf spots which attack the cassava plant in the generative phase, especially near the age of harvest. In addition, Nuabosi cassava is also tolerant of drought, has a savory taste and high starch content by $33.33 \%$. The statement above illustrates that how important it is to maintain the existence of cassava, for this reason, it is necessary to make an effort to maintain the condition of the land to remain sustainable. One step that can be taken is managing various agricultural activities so that soil fertility is maintained.

Agricultural activities carried out on Nuabosi cassava cultivation land are very high. This happens because the land not only cultivates cassava but also cultivated with various horticultural plants. This cropping pattern impacts on rapidly decreasing soil fertility (Wahyuningtyas, 2010; Andreawan et al., 2015; Muhammad et al., 2015). Considering soil fertility is an important factor in supporting the existence of Nuabosi cassava, it is necessary to conduct the research on Identification of Agricultural Activities and Soil Fertility in Nuabosi Cassava Cultivation Field in Ende District, Ende Regency. The results of this study have contributed greatly to the creation of sustainable agriculture. This is because the data obtained from the research results can illustrate the current condition of agricultural land (especially land cultivating Nuabosi cassava) and appropriate efforts to maintain the sustainability of germplasm land and resources.

\section{MATERIALS AND METHOD}

This study used a survey system and conducted from March to July 2018. The research sites are in Embuteru, Ndetundora I, Ndetundora II, Ndetundora III and Randotonda Villages, Ende District, Ende Regency. The selection of land as the location of the study used a purposive sampling method.

The research location were Andisol soil type which is developed from volcanic material. Taking the soil samples using disturbed soil sampling techniques, samples of intact aggregate soil and intact soil samples. While the sampling technique of farmers for instruction was conducted by purposive sampling.

The variables observed were the physical and chemical properties of the soil and the activities of farmers. The physical properties of the soil observed were soil texture (pipette method), structure (qualitative method), soil color (comparison with the Munsell Soil Color Charts), effective depth (observation in the field), landslope (observed with Abney level) and altitude (observed with the Global Positioning System). The soil chemical properties observed were N-Total (Kjeldahl method), P-Available (Brayz ${ }^{-1}$ method), Potassium (Bray ${ }^{-1}$ method), COrganic (Walkey and Black method), soil acidity (pH) ( $\mathrm{pH}$ metermethod), Cation Exchange Capacity (CEC) (Basic Percolation Method) and Base Saturation, while farmer activity data is obtained by means of interviews and direct observation in the field. Farmer samples for interviewing were obtained by purposive sampling method. With this method, the farmers interviewed were 20 people whose land was used as a place for sampling soil.

Data on soil physical properties obtained were analyzed descriptively to illustrate their suitability for cassava plants, while soil chemical data were 
determined by chemical criteria using a reference to soil chemical criteria from the Bogor Soil Research Center (Pusat Penelitian Tanah, 1995). Besides that, the fertility rate was determined by using a reference to soil fertility criteria from the Bogor Soil Research Center (Pusat Penelitian Tanah, 1995).

\section{RESULTS AND DISCUSSION}

\section{Agriculture activities}

Agricultural activities were greatly affected to the fertility of the land. Data on cassava farmer activities in Embuteru, Ndetundora I, Ndetundora II, Ndetundora III and Randotonda villages can be seen in Table 1 .
Interviews and direct observations in the field showed that farmers not only planted Nuabosi cassava on their land but also vegetables and corn (polyculture). The polyculture planting pattern can have a positive or negative impact on the productivity of plants and land. Polyculture planting patterns by combining cassava plants with legume plants have an impact on increasing crop yields and soil fertility (Adjei-Nsiah et al., 2007; Pypers et al., 2011; Ogola et al., 2013). This is also related to the cultivation of land that is carried out because of the existence of several plants that are cultivated in one field. The results of the study from Silalahi et al. (2016) states that intensive tillage without regard to the factors that influence it can reduce soil quality.

Table 1. Agricultural activities in land in Embuteru, Ndetundora I, Ndetundora II, Ndetundora III and Randotonda Villages

\begin{tabular}{|c|c|c|c|c|c|}
\hline \multirow{2}{*}{$\begin{array}{l}\text { Agricultural } \\
\text { activities }\end{array}$} & \multicolumn{5}{|c|}{ Villages } \\
\hline & Embuteru & Ndetundora I & Ndetundora II & Ndetundora III & Randotonda \\
\hline $\begin{array}{l}\text { Cropping } \\
\text { pattern }\end{array}$ & $\begin{array}{l}\text { Cassava (Tana } \\
\text { ai and Terigu), } \\
\text { mustard and } \\
\text { spinach are } \\
\text { cultivated with } \\
\text { intercropping }\end{array}$ & $\begin{array}{l}\text { Cassava (Tana } \\
\text { ai), corn, } \\
\text { mustard greens } \\
\text { and beans are } \\
\text { cultivated with } \\
\text { intercropping }\end{array}$ & $\begin{array}{l}\text { Cassava (terigu), } \\
\text { Chinese cabbage } \\
\text { and long beans } \\
\text { are cultivated } \\
\text { with } \\
\text { intercropping }\end{array}$ & $\begin{array}{l}\text { Cassava (Tana } \\
\text { ai), beans and } \\
\text { mustard flowers } \\
\text { are cultivated } \\
\text { with } \\
\text { intercropping }\end{array}$ & $\begin{array}{l}\text { Cassava (Tana } \\
\text { ai and terigu), } \\
\text { mustard and } \\
\text { long beans are } \\
\text { cultivated with } \\
\text { intercropping }\end{array}$ \\
\hline Soil tillage & $\begin{array}{l}\text { The land is } \\
\text { hijacked using } \\
\text { the hoesonce, } \\
\text { then the grass is } \\
\text { buried in the soil }\end{array}$ & $\begin{array}{l}\text { The land is } \\
\text { hijacked using } \\
\text { the hoes } 3 \\
\text { times, then } \\
\text { buried with } \\
\text { grass and leaves }\end{array}$ & $\begin{array}{l}\text { The land is } \\
\text { hijacked using a } \\
\text { tractor once and } \\
\text { then made beds } \\
\text { and grass buried }\end{array}$ & $\begin{array}{l}\text { The land is } \\
\text { hijacked using } \\
\text { the hoes } 2 \text { times, } \\
\text { then made beds } \\
\text { and grass and } \\
\text { leaves buried }\end{array}$ & $\begin{array}{l}\text { The land is } \\
\text { hijacked using } \\
\text { the hoes } 2 \text { times, } \\
\text { then buried grass } \\
\text { and cow waste }\end{array}$ \\
\hline Fertilization & $\begin{array}{l}\text { Fertilization is } \\
\text { not done }\end{array}$ & $\begin{array}{l}\text { Fertilization is } \\
\text { not done }\end{array}$ & $\begin{array}{l}\text { Livestock waste, } \\
\text { Za and Green tonic }\end{array}$ & $\begin{array}{l}\text { Use fertilizer } \\
\text { for vegetables }\end{array}$ & $\begin{array}{l}\text { Fertilization is } \\
\text { not done }\end{array}$ \\
\hline $\begin{array}{l}\text { Plant } \\
\text { maintenance }\end{array}$ & $\begin{array}{l}\text { Mechanical } \\
\text { weeding is done } \\
\text { twice }\end{array}$ & $\begin{array}{l}\text { Mechanical } \\
\text { weeding is done } \\
\text { twice }\end{array}$ & $\begin{array}{l}\text { Mechanical } \\
\text { weeding is done } \\
3 \text { times and } \\
\text { spraying pests } \\
\text { with organic } \\
\text { pesticides }\end{array}$ & $\begin{array}{l}\text { Mechanical } \\
\text { weeding is done } \\
3 \text { times and } \\
\text { spraying pests } \\
\text { with synthetic } \\
\text { Pesticides }\end{array}$ & $\begin{array}{l}\text { Mechanical } \\
\text { weeding is done } \\
\text { twice and } \\
\text { spraying pests } \\
\text { with synthetic } \\
\text { pesticides }\end{array}$ \\
\hline Harvest & $\begin{array}{l}\text { The harvest age } \\
\text { of cassava is } \pm 1 \\
\text { year, while } \\
\text { mustard and } \\
\text { spinach are } 3 \\
\text { weeks }\end{array}$ & $\begin{array}{l}\text { The harvest age } \\
\text { of cassava is } 1 \\
\text { year, } 10 \text { weeks } \\
\text { of mustard } \\
\text { greens, beans } \\
\text { and corn } 3 \\
\text { weeks }\end{array}$ & $\begin{array}{l}\text { The harvest age } \\
\text { of cassava is } 1 \\
\text { year, Chinese } \\
\text { cabbage is } 2 \\
\text { months and long } \\
\text { beans are } 7 \text { weeks }\end{array}$ & $\begin{array}{l}\text { The harvest age } \\
\text { of cassava is } 10 \\
\text { months, } \\
\text { mustard } 1 \\
\text { month, beans } 2 \\
\text { months. }\end{array}$ & $\begin{array}{l}\text { The harvest age } \\
\text { of cassava is } \pm \\
1 \text { year, } 3 \text { weeks } \\
\text { of mustard } \\
\text { greens and } 3 \\
\text { weeks of long } \\
\text { beans }\end{array}$ \\
\hline
\end{tabular}

Regarding to the land processing, the results of the study show that farmers cultivate their land before planting. Processing carried out includes hoeing, inserting grass and cow waste into the soil 
(cow waste that does not go through the fermentation process). The tillage is a conservative soil treatment action. Appropriate soil treatment measures can reduce soil damage due to the long-term effects of cultivating cassava plants (Howeler, 1991). This is supported by Lal (2001) which states that the higher the land processing activity, the erosion rate will be even greater.

In addition to land processing activities, there are several other activities that affect to the quality of cassava land. These activities are fertilizing, weeding, spraying pesticides and harvesting cassava. These activities have an effect on changes in soil fertility and cassava crop yields and the sustainability of land use (Hutauruk et al., 2012; Kintché et al., 2017; Nakabonge et al., 2018).

\section{The physical properties of the soil}

The physical properties of the soil greatly influence the growth and development of cultivated plants. The physical properties of soil on land in Embuteru, Ndetundora I, Ndetundora II, Ndetundora III and Randotonda villages can be seen in Table 2.

Table 2. The physical properties of soil

\begin{tabular}{|c|c|c|c|c|c|c|}
\hline $\begin{array}{l}\text { Sample } \\
\text { code }\end{array}$ & $\begin{array}{l}\text { Altitude of } \\
\text { place (masl) }\end{array}$ & $\begin{array}{l}\text { Slope } \\
(\%)\end{array}$ & $\begin{array}{c}\text { Soil } \\
\text { texture }\end{array}$ & $\begin{array}{c}\text { Soil } \\
\text { structure }\end{array}$ & $\begin{array}{c}\text { Soil } \\
\text { colour }\end{array}$ & $\begin{array}{l}\text { Effective } \\
\text { depth }(\mathrm{cm})\end{array}$ \\
\hline NL ND 1 & 520 & 3.2 & $\begin{array}{l}\text { Loamy } \\
\text { Sand }\end{array}$ & $\begin{array}{l}\text { Angular } \\
\text { Bloky }\end{array}$ & $\begin{array}{l}\text { Dark Bluis } \\
\text { Gray }\end{array}$ & $>40$ \\
\hline NL ND 2 & 546 & 3.0 & $\begin{array}{l}\text { Loamy } \\
\text { Sand }\end{array}$ & $\begin{array}{l}\text { Angular } \\
\text { Bloky }\end{array}$ & $\begin{array}{l}\text { Dark Bluis } \\
\text { Gray }\end{array}$ & $>40$ \\
\hline NL ND 3 & 554 & 5.0 & $\begin{array}{l}\text { Loamy } \\
\text { Sand }\end{array}$ & $\begin{array}{l}\text { Angular } \\
\text { Bloky }\end{array}$ & $\begin{array}{l}\text { Dark Bluis } \\
\text { Gray }\end{array}$ & $>40$ \\
\hline NL RT & 588 & 3.0 & $\begin{array}{l}\text { Loamy } \\
\text { Sand }\end{array}$ & $\begin{array}{l}\text { Angular } \\
\text { Bloky }\end{array}$ & $\begin{array}{c}\text { Dark Bluis } \\
\text { Gray }\end{array}$ & $>40$ \\
\hline NL E & 558 & 29.0 & $\begin{array}{l}\text { Loamy } \\
\text { Sand }\end{array}$ & $\begin{array}{c}\text { Sub Angular } \\
\text { Bloky }\end{array}$ & $\begin{array}{c}\text { Dark Greenish } \\
\text { Gray }\end{array}$ & $<30$ \\
\hline L ND 1 & 520 & 3.2 & $\begin{array}{l}\text { Loamy } \\
\text { Sand }\end{array}$ & $\begin{array}{c}\text { Sub Angular } \\
\text { Bloky }\end{array}$ & $\begin{array}{c}\text { Dark Greenish } \\
\text { Gray }\end{array}$ & $>40$ \\
\hline L ND 2 & 546 & 3.0 & $\begin{array}{l}\text { Loamy } \\
\text { Sand }\end{array}$ & $\begin{array}{c}\text { Sub Angular } \\
\text { Bloky }\end{array}$ & $\begin{array}{c}\text { Dark Greenish } \\
\text { Gray }\end{array}$ & $>40$ \\
\hline L ND 3 & 554 & 5.0 & $\begin{array}{l}\text { Loamy } \\
\text { Sand }\end{array}$ & $\begin{array}{c}\text { Sub Angular } \\
\text { Bloky }\end{array}$ & $\begin{array}{c}\text { Dark Greenish } \\
\text { Gray }\end{array}$ & $>40$ \\
\hline L RT & 588 & 3.0 & $\begin{array}{l}\text { Loamy } \\
\text { Sand }\end{array}$ & $\begin{array}{c}\text { Sub Angular } \\
\text { Bloky }\end{array}$ & $\begin{array}{c}\text { Dark Greenish } \\
\text { Gray }\end{array}$ & $>40$ \\
\hline LE & 558 & 29.0 & $\begin{array}{l}\text { Loamy } \\
\text { Sand }\end{array}$ & $\begin{array}{c}\text { Sub Angular } \\
\text { Bloky }\end{array}$ & $\begin{array}{c}\text { Dark Greenish } \\
\text { Gray }\end{array}$ & $<30$ \\
\hline
\end{tabular}

Note: $\mathrm{NL}=$ Non-cultivated land; $\mathrm{L}=$ Land; ND $1=$ Ndetundora $1, \mathrm{ND} 2=$ Ndetundora 2, ND $3=$ Ndetundora 3 ; $\mathrm{RT}=$ Rendotonda $; \mathrm{E}=$ Embuteru

The results showed that Nuabosi cassava plants grew in areas with an altitude of 520-588 m above sea level (MASL) which is its height still in the appropriate category. According to Sundari (2010), the altitude for cassava plants varies from an altitude of $150-1,500$ MASL. The ability to grow with a wide range of heights causes altitude not to be an inhibiting factor for the growth and development of cassava plants (Muhammad and Wasit, 2015). The appropriate altitude for cassava plants is positively correlated with the slope.

The slope of land greatly determines the level of fertility of a land and the amount of erosion that occurs. The results showed that the slope of agricultural land in the four villages producing Nuabosi cassava was in the range by $3-5 \%$, while the land in Embuteru Village had a slope of $29 \%$. The slope of 3-5\% indicates that the land is at the level of moderate suitable (S2) (Ritung et al., 2011). While the land with a slope by $29 \%$ in the village of Embuteru falls into the not suitable category (N) (Nurwansyah, 2012). Slope also has an impact on changes in soil texture.

The results of soil texture class analysis showed that there was no difference in soil texture from the ten samples studied (loamy sand texture). 
Something similar happened to the soil structure, where all the samples of the soil studied were still in the blocky group. This condition is influenced by the planting pattern applied by Nuabosi cassava farmers and the use of low-dose inorganic fertilizers (Arifin, 2010; Suroyo et al., 2013; Margolang et al., 2015;). Whereas when viewed from the land suitability, the soil texture of sandy is quite suitable for cassava plants (Diallo et al., 2016). Other variables seen in this study are soil color and effective depth.

Soil color observed in the field shows that the land has a striking black and grayish soil color, dark bluis gray and dark greenish gray. This is supported by the statement of Harist et al. (2017), which states that soil color is influenced by the level of maturity of organic matter. As for the effective depth, the results of the study show that the soil studied has an effective depth of $>40 \mathrm{~cm}$. Based on the land suitability classification, the conditions fall into the moderate suitable category (S2). It is mean that the land has mild limiting factors that affect its productivity, so it requires additional input from outside sources (Hardjowigeno and Widiatmika, 2011).

\section{Soil chemical properties}

The results of the analysis of soil chemical properties from the five villages producing Nuabosi cassava can be seen in Table 3 .

Table 3. Characteristics of soil chemical properties

\begin{tabular}{llcccccc}
\hline $\begin{array}{c}\text { Sample } \\
\text { code }\end{array}$ & $\begin{array}{c}\text { C-Organic } \\
(\%)\end{array}$ & $\begin{array}{c}\mathrm{N} \\
(\%)\end{array}$ & $\begin{array}{c}\mathrm{P} \\
(\mathrm{ppm})\end{array}$ & $\begin{array}{c}\mathrm{K} \\
\left(\mathrm{cmol}+\mathrm{kg}^{-1}\right)\end{array}$ & $\begin{array}{c}\mathrm{CEC} \\
\left(\mathrm{cmol}+\mathrm{kg}^{-1}\right)\end{array}$ & $\begin{array}{c}\mathrm{BS} \\
(\%)\end{array}$ & $\mathrm{pH}$ \\
\hline NLND 1 & $0.06 \mathrm{VL}$ & $0.18 \mathrm{~L}$ & $16.79 \mathrm{M}$ & $0.72 \mathrm{VH}$ & $38.60 \mathrm{H}$ & $55.98 \mathrm{H}$ & $6.65 \mathrm{~N}$ \\
NLND 2 & $0.06 \mathrm{VL}$ & $0.11 \mathrm{~L}$ & $16.91 \mathrm{M}$ & $0.73 \mathrm{VH}$ & $38.15 \mathrm{H}$ & $56.68 \mathrm{H}$ & $6.58 \mathrm{RA}$ \\
NLND 3 & $0.76 \mathrm{VL}$ & $0.19 \mathrm{~L}$ & $15.00 \mathrm{~L}$ & $0.63 \mathrm{VH}$ & $38.23 \mathrm{H}$ & $53.37 \mathrm{H}$ & $6.50 \mathrm{RA}$ \\
NLRT & $0.52 \mathrm{VL}$ & $0.16 \mathrm{~L}$ & $16.43 \mathrm{M}$ & $0.71 \mathrm{VH}$ & $37.83 \mathrm{H}$ & $57.11 \mathrm{H}$ & $6.20 \mathrm{RA}$ \\
NLE & $1.78 \mathrm{~L}$ & $0.28 \mathrm{M}$ & $19.47 \mathrm{M}$ & $0.87 \mathrm{VH}$ & $39.14 \mathrm{H}$ & $67.23 \mathrm{H}$ & $6.76 \mathrm{~N}$ \\
L ND 1 & $0.70 \mathrm{VL}$ & $0.24 \mathrm{M}$ & $19.11 \mathrm{M}$ & $0.85 \mathrm{VH}$ & $37.38 \mathrm{H}$ & $65.91 \mathrm{H}$ & $6.84 \mathrm{~N}$ \\
L ND 2 & $1.06 \mathrm{~L}$ & $0.27 \mathrm{M}$ & $14.80 \mathrm{~L}$ & $0.63 \mathrm{VH}$ & $37.97 \mathrm{H}$ & $55.56 \mathrm{H}$ & $6.35 \mathrm{RA}$ \\
L ND 3 & $0.72 \mathrm{VL}$ & $0.18 \mathrm{~L}$ & $17.99 \mathrm{M}$ & $0.80 \mathrm{VH}$ & $35.92 \mathrm{H}$ & $64.82 \mathrm{H}$ & $6.52 \mathrm{RA}$ \\
L RT & $1.88 \mathrm{~L}$ & $0.29 \mathrm{M}$ & $17.78 \mathrm{M}$ & $0.78 \mathrm{VH}$ & $38.48 \mathrm{H}$ & $63.87 \mathrm{H}$ & $6.55 \mathrm{RA}$ \\
LE & $0.05 \mathrm{VL}$ & $0.10 \mathrm{VL}$ & $18.79 \mathrm{M}$ & $0.83 \mathrm{VH}$ & $37.89 \mathrm{H}$ & $62.18 \mathrm{H}$ & $6.56 \mathrm{RA}$ \\
\hline
\end{tabular}

Note: $\mathrm{VL}=$ =Very low; $\mathrm{L}=$ Low; $\mathrm{M}=$ Moderate; $\mathrm{Vh}=$ Very high; $\mathrm{H}=$ High; $\mathrm{RA}=$ Rather acidic; $\mathrm{N}=$ Neutral

The results showed that the $\mathrm{C}$-Organic content of the ten soil samples was in the very low to the low category. The low C-Organic soil can be influenced by the level of soil tillage. This is in line with the results of research conducted by (Rachman et al., 2015) that uses the treatment level of land processing on corn plants shows that intensive tillage affects the lower organic matter content.

In addition to C-Organic, other important elements for plants are Nitrogen $(\mathrm{N})$ and Phosphorus (P). The data in Table 3 shows that existing agricultural activities cause the $\mathrm{N}$ and $\mathrm{P}$ content to be in the low to moderate range. This is in line with the results of research conducted by (Deliyana et al., 2016) study with the treatment of the soil treatment system showed that perfectly treated soil had the highest nutrient content of the soil and crop production compared to other treatments.
Things that are different from nutrients $\mathrm{N}$ and $\mathrm{P}$ are indicated by the element Potassium (K). The results of the research that have been conducted show that $\mathrm{K}$ which is in agricultural land has a very high content. This condition can occur because the land is mostly processed by immersing litter and organic matter into the soil. Immersing of these materials causes the soil not to lose nutrients easily (Indria, 2005; Rahmah et al., 2014; Deliyana et al., 2016). In addition, to increase nutrient content in the soil, the application of organic matter also has an impact on high cation exchange capacity (CEC) and base saturation (BS).

\section{Soil fertility criteria}

Data on the results of the assessment of soil fertility in Embuteru, Ndetundora I, Ndetundora II, Ndetundora III and Randotonda Villages are presented in Table 4. 
Table 4. Soil fertility criteria

\begin{tabular}{lcccccc}
\hline $\begin{array}{c}\text { Sample } \\
\text { code }\end{array}$ & $\begin{array}{c}\text { CEC } \\
\left(\mathrm{cmol}+\mathrm{kg}^{-1}\right)\end{array}$ & $\begin{array}{c}\text { BS } \\
\%\end{array}$ & $\begin{array}{c}\mathrm{P} \\
(\mathrm{ppm})\end{array}$ & $\begin{array}{c}\mathrm{K} \\
\left(\mathrm{cmol}+\mathrm{kg}^{-1}\right)\end{array}$ & $\begin{array}{c}\text { C-Organic } \\
(\%)\end{array}$ & $\begin{array}{c}\text { Soil fertility } \\
\text { status }\end{array}$ \\
\hline NL ND 1 & $38.60 \mathrm{H}$ & $55.98 \mathrm{M}$ & $16.79 \mathrm{VH}$ & $0.72 \mathrm{VL}$ & $0.06 \mathrm{VL}$ & Low \\
NL ND 2 & $38.15 \mathrm{H}$ & $56.68 \mathrm{M}$ & $16.91 \mathrm{VH}$ & $0.73 \mathrm{VL}$ & $0.06 \mathrm{VL}$ & Low \\
NL ND 3 & $38.23 \mathrm{H}$ & $53.37 \mathrm{M}$ & $15.00 \mathrm{VH}$ & $0.63 \mathrm{VL}$ & $0.76 \mathrm{VL}$ & Low \\
NL RT & $37.83 \mathrm{H}$ & $57.11 \mathrm{M}$ & $16.43 \mathrm{VH}$ & $0.71 \mathrm{VL}$ & $0.52 \mathrm{VL}$ & Low \\
NL E & $39.14 \mathrm{H}$ & $67.23 \mathrm{M}$ & $19.47 \mathrm{VH}$ & $0.87 \mathrm{VL}$ & $1.78 \mathrm{VL}$ & Low \\
L ND 1 & $37.38 \mathrm{H}$ & $65.91 \mathrm{M}$ & $19.11 \mathrm{VH}$ & $0.85 \mathrm{VL}$ & $0.70 \mathrm{VL}$ & Low \\
L ND 2 & $37.97 \mathrm{H}$ & $55.56 \mathrm{M}$ & $14.80 \mathrm{H}$ & $0.63 \mathrm{VL}$ & $1.60 \mathrm{VL}$ & Low \\
L ND 3 & $35.92 \mathrm{H}$ & $64.82 \mathrm{M}$ & $17.99 \mathrm{VH}$ & $0.80 \mathrm{VL}$ & $0.72 \mathrm{VL}$ & Low \\
L RT & $38.48 \mathrm{H}$ & $63.87 \mathrm{M}$ & $17.78 \mathrm{VH}$ & $0.78 \mathrm{VL}$ & $1.88 \mathrm{VL}$ & Low \\
LE & $37.89 \mathrm{H}$ & $62.18 \mathrm{M}$ & $18.79 \mathrm{VH}$ & $0.83 \mathrm{VL}$ & $0.05 \mathrm{VL}$ & Low \\
\hline
\end{tabular}

Note: $\mathrm{VH}=$ Very High; $\mathrm{H}=$ High; $\mathrm{M}=$ Moderate; $\mathrm{L}=$ Low; $\mathrm{VL}=$ Very Low

The criteria for soil fertility in existing land in the villages of Ndetundora I, Ndetundora II, Ndetundora III, Embuteru and Randotonda is shown in Table 4 show that these lands are on low fertility criteria. Factor that cause low soil fertility is $\mathrm{C}$-Organic. Fertile soil has nutrients available to plants and there are no limiting factors in the soil.

Many agricultural lands are currently very low in organic matter. This is in accordance with the results of research conducted by Husni et al. (2016) that the evaluation of soil fertility carried out on several types of soil on dry land indicate a lack of C-Organic conditions. For this reason, it is necessary to add organic matter and organic fertilizer so that it can increase soil fertility.

\section{CONCLUSIONS}

Based on the results of the study, agricultural activities carried out by cassava farmers Nuabosi are conservative such as immersion of grass when the soil hijacked, minimum tillage and without the use of synthetic fertilizers and pesticides. And based on soil fertility criteria, the farmer's land has low fertility with a limiting factor, namely C-Organic.

\section{ACKNOWLEDGEMENT}

The author would like to thank the DPRM Kemenristekdikti for funding all research activities (SK Director General of Strengthening Research and Development of the Ministry of Research, Technology and Higher Education of the Republic of Indonesia No.3/E/KPT/2018 concerning Acceptance of Research Funding in Higher Education 2018 for Flores University).

\section{REFERENCES}

Adjei-Nsiah, S., Kuyper, T. W., Leeuwis, C., Abekoe, M. K., \& Giller, K. E. (2007). Evaluating Sustainable and Profitable Cropping Sequences with Cassava and Four Legume Crops: Effects on Soil Fertility and Maize Yields in the Forest/Savannah Transitional Agro-Ecological Zone of Ghana. Field Crops Research, 103(2), 87-97. https://doi.org/10.1016/j.fcr.2007.05.001

Andreawan, M. K., Banuwa, I. S., \& Zulkarnain, I. (2015). Pengaruh Sistem Olah Tanah terhadap Aliran Permukaan dan Erosi pada Pertanaman Singkong di Laboratorium Lapang Terpadu Fakultas Pertanian Universitas Lampung. Jurnal Teknik Pertanian Lampung, 4(1), 27-34. Retrieved from https://media.neliti.com/media/ publications/142840-ID-none.pdf

Arifin, M. (2010). Kajian Sifat Fisik Tanah dan Berbagai Penggunaan Lahan dalam Hubungannya dengan Pendugaan Erosi Tanah. Jurnal Pertanian MAPETA, 12(2), 72-144. https://doi.org/10.1016/S0031-9422(03) 00269-3

Deliyana, Lumbanraja, J., Sunyoto, \& Utomo. (2016). Pengaruh Pengolahan Tanah terhadap Pertumbuhan, Produksi dan Serapan Hara Ubi kayu (Manihot Esculenta Crantz) pada Periode Tanam ke-2 di Gedung. Jurnal.fp.unila.ac.id, 4(3), 233-239. Retrieved from http://jurnal.fp.unila.ac.id/index.php/JA/ article/view/1858

Dewanto, F. G., Londok, J. J. M. R., Tuturoong, 
\& Kaunang. (2013). Pengaruh Pemupukan Organik dan Anorganik terhadap Produksi Tanaman Jagung sebagai Sumber Pakan. Zootek, 32(5), 1-8. Retrieved from https:// ejournal.unsrat.ac.id/index.php/zootek/article/ download/982/795

Diallo, M. D., Wood, S. A., Diallo, A., MahatmaSaleh, M., Ndiaye, O., Tine, A. K., Guisse, A. (2016). Soil Suitability for the Production of Rice, Groundnut and Cassava in the PeriUrban Niayes Zone, Senegal. Soil and Tillage Research, 155, 412-420. https://doi.org/ 10.1016/j.still.2015.09.009

Dinas Pertanian Kabupaten Ende. (2017). Kabupaten Ende dalam Angka. BPS Kabupaten Ende (Vol. 91). Retrieved from https://endekab.bps.go.id/publication/downloa d.html?nrbvfeve=N2Q2NTFIYTg3ZmUzMT BlYjA4OTc5ZmIw\&xzmn=aHR0cHM6Ly91 bmRla2FiLmJwcy5nby5pZC9wdWJsaWNhd Glvbi8yMDE3LzA4LzEyLzdkNjUxZWE4N 2ZIMzEwZWIwODk3OWZiMC9rYWJ1cGF 0ZW4tZW5kZS1kYWxhbS1hbmdrYS0yMD E3Lmh0bWw\%3D\&twoad

Hardjowigeno, S., \& Widiatmika. (2011). Evaluasi Kesesuaian Lahan dan Perencanaan Tata Guna Lahan. Yogyakarta: Gajah Mada University Press.

Harist, A., Wawan, \& Wardati. (2017). Sifat Fisik Tanah dan Pertumbuhan Tanaman Karet (Hevea brasiliensis Muell. Arg) pada Beberapa Kondisi Penutupan Lahan dengan Mucuna bracteata. JOM Faperta UR, 4(2), 114. Retrieved from https://jom.unri.ac.id/ index.php/JOMFAPERTA/article/download/1 $6967 / 16383$

Howeler, R. H. (1991). Long-Term Effect of Cassava Cultivation on Soil Productivity. Field Crops Research, 26(1), 1-18. https://doi.org/10.1016/0378-4290(91)90053$\mathrm{X}$

Husni, M. R., Sufardi, \& Khalil, M. (2016). Evaluasi Status Kesuburan pada Beberapa Jenis Tanah di Lahan Kering Kabupaten Pidie Provinsi Aceh. Jurnal Ilmiah Mahasiswa Pertanian Unsyiah, 1(1), 147-154. Retrieved from http://jim.unsyiah.ac.id/JFP/article/ download/950/1346

Hutauruk, F. I., Simanungkalit, T., \& Irmansyah,
T. (2012). Pengujian Pemberian Fungi Mikoriza Arbuskula dan Pupuk Fosfat pada Budidaya Tanaman Sorgum (Sorghum bicolor (L.) Moench). Jurnal Online Agroekoteknologi, 1(1), 64-76. Retrieved from https://media.neliti.com/media/ publications/93900-ID-none.pdf

Indria, A. (2005). Pengaruh Sistem Pengolahan Tanah dan Pemberian Macam Bahan Organik terhadap Pertumbuhan dan Hasil Kacang Tanah (Arachis hypogaea L.). Universitas Surakarta. Retrieved from https://core.ac.uk/ download/pdf/12347547.pdf

Kintché, K., Hauser, S., Mahungu, N. M., Ndonda, A., Lukombo, S., Nhamo, N., Vanlauwe, B. (2017). Cassava Yield Loss in Farmer Fields was Mainly Caused by Low Soil Fertility and Suboptimal Management Practices in Two Provinces of the Democratic Republic of Congo. European Journal of Agronomy, 89, 107-123. https://doi.org/ 10.1016/j.eja.2017.06.011

Lal, R. (2001). Soil Degradation by Erosion. Land Degradation and Development, 12, 519-539. https://doi.org/10.1002/ldr.472

Lestari, A. P. (2009). Pengembangan Pertanian Berkelanjutan Melalui Subtitusi Pupuk Anorganik dengan Pupuk Organik. Jurnal Agronomi, 13(1), 38-44. Retrieved from http://download.garuda.ristekdikti.go.id/articl e.php?article $=11971 \&$ val $=876 \&$ title $=$ PENGE MBANGAN PERTANIAN BERKELANJUTAN MELALUI SUBTITUSI PUPUK ANORGANIK DENGAN PUPUK ORGANIK

Margolang, R. D., Jamilah, \& Sembiring, M. (2015). Karakteristik Beberapa Sifat Fisik, Kimia, dan Biologi Tanah pada Sistem Pertanian Organik. Jurnal Online Agroekoteaknologi, 3(2), 717-723. Retrieved from https://media.neliti.com/media/ publications/104544-ID-karakteristikbeberapa-sifat-fisik-kimia.pdf

Masniah, \& Yusuf. (2013). Potensi Ubi Kayu sebagai Pangan Fungsional. In Prosiding Seminar Hasil Penelitian Tanaman Aneka Kacang dan Umbi (pp. 580-587). Retrieved from http://balitkabi.litbang.pertanian.go.id/ wp-content/uploads/2017/02/prosiding_2013_ 4_11.pdf 
Muhammad, Darusman, \& Chairunnas. (2015). Aplikasi Biochar, Kompos dan Urea terhadap Beberapa Sifat Fisika Tanah, Pertumbuhan, dan Hasil Tanaman Kaylan (Brassica oleraceae). Jurnal Ilmu Kebencanaan (JIKA), 2(4), 217-226. Retrieved from http://balitkabi. litbang.pertanian.go.id/wp-content/uploads/ 2017/02/prosiding_2013_4_11.pdf

Muhammad, \& Wasit, U. (2015). Kesesuaian Lahan untuk Tanaman Pangan di Kabupaten Madiun. Gontor Agrotech Science Journal, 1(2), 71-93. https://doi.org/10.21111/ agrotech.v1i2.265

Mulyanti, S. S., Made, U., \& Wahyudi, I. (2015). Pengaruh Pemberian Berbagai Jenis Bokashi terhadap Pertumbuhan dan Hasil Tanaman Jagung. Jurnal Agrotekbis, 3(5), 592-601. Retrieved from http://jurnal.untad.ac.id/jurnal/ index.php/Agrotekbis/article/viewFile/5277/4 028

Nakabonge, G., Samukoya, C., \& Baguma, Y. (2018). Local Varieties of Cassava: Conservation, Cultivation and Use in Uganda. Environment, Development and Sustainability, 20, 2427-2445. https://doi.org/10.1007/s10 668-017-9997-6

Nurwansyah, M. A. (2012). Karakteristik Tanah dan Lahan untuk Kesesuaian Lahan Ubikayu (Manihot spp.). Institut Pertanian Bogor. Retrieved from https://repository.ipb.ac.id/ jspui/bitstream/123456789/60092/1/A12man. pdf

Ogola, J. B., Mathewa, C., \& Magongwa, S. (2013). The Productivity of Cassava - Legume Intercropping System in a Dry Environment in Nelspruit, South Africa. African Crop Science Conference Proceedings, 11, 61-65. https:// doi.org/10.1007/s00115-010-3064-y

Pusat Penelitian Tanah, [PPT]. (1995). Petunjuk Teknis Evaluasi Kesuburan Tanah.

Pusat Perlindungan Varietas Tanaman dan Perizinan Pertanian. (2016). Laporan Tahunan Pusat Perlindungan Varietas Tanaman dan Perizinan Pertanian Tahun 2015. Jakarta. Retrieved from http://pvtpp.setjen.pertanian. go.id/cms2017/wp-content/uploads/2016/06/ LapTan-2015-1.pdf

Pypers, P., Sanginga, J. M., Kasereka, B., Walangululu, M., \& Vanlauwe, B. (2011).
Increased Productivity Through Integrated Soil Fertility Management in Cassava-Legume Intercropping Systems in the Highlands of Sud-Kivu, DR Congo. Field Crops Research, 120, 76-85. https://doi.org/10.1016/j.fcr.2010. 09.004

Rachman, L. M., Latifia, N., \& Nuruida, N. (2015). Efek Sistem Pengolahan Tanah terhadap Bahan Organik Tanah, Sifat Fisik Tanah dan Produksi Jagung pada Tanah Podsolik Merah Kuning di Kabupaten Lampung Timur. In Prosiding Seminar Nasional Lahan Suboptimal (Vol. 91, pp. 399 404). Sriwijaya: Universitas Sriwijaya. Retrieved from http://pur-plso.unsri.ac.id/ userfiles/PROSIDING PUR PLSO 2015 FULL.pdf

Rahmah, S., Yusran, \& Umar, H. (2014). Sifat Kimia Tanah pada Berbagai Tipe Penggunaan Lahan di Desa Bobo Kecamatan Palolo Kabupaten Sigi. Warta Rimba, 2(1), 88-95. Retrieved from http://jurnal.untad.ac.id/ jurnal/index.php/WartaRimba/article/view/35 $79 / 2592$

Ritung, S., Nugroho, K., Mulyani, A., \& Suryani, E. (2011). Petunjuk Teknis Evaluasi Lahan untuk Komoditas Pertanian (Revisi). Bogor: Balai Besar Penelitian dan Pengembangan Sumber Daya Lahan Pertanian, Badan Pertanian dan Pengembagan Sumberdaya lahan Pertanian. https://doi.org/10.1039/ c6qm00199h

Sarno. (2009). Pengaruh Kombinasi NPK dan Pupuk Kandang terhadap Sifat Tanah dan Pertumbuhan serta Produksi Tanaman Caisim. Jurnal Tanah Trop, 14(3), 211-219. Retrieved from http://repository.lppm.unila.ac.id/956/1/ Sarno 37-2247-1-PB.pdf

Silalahi, S. M., Lubis, K. S., \& Hanum, H. (2016). Kajian Hubungan Kadar Liat, Bahan Organik dan Kadar Air terhadap Indeks Plastisitas Tanah di Kecamatan Jorlang Hantaran Kabupaten Simalungun. Jurnal Agroekoteknologi, 4(4), 2316-2323. Retrieved from https://media.neliti.com/media/ publications/108708-ID-kajian-hubungankadar-liat-bahan-organik.pdf

Sundari, T. (2010). Petunjuk Teknis Pengenalan Varietas Unggul dan Teknik Budidaya Ubi kayu. Malang. 
Suroyo, S., Suntoro, S., \& Suryono, S. (2013). Sistem Tumpangsari dan Integrasi Ternak Terhadap Perubahan Sifat Fisik dan Kimia Tanah di Tanah Litosol. Sains Tanah, 10(1), 71-80. https://doi.org/10.15608/stjssa.v13i2. 521

Susilawati, Nurdjanah, S., \& Putri, S. (2008). Karakter Sifat Fisik dan Kimia Ubi Kayu (Manihot esculenta) Berdasarkan Lokasi Penanaman dan Umur Panen Berbeda. Jurnal Teknologi Industri dan Hasil Pertanian, 13(2), 59-72. Retrieved from http://repository. lppm.unila.ac.id/3594/1/lokasi ubikayu68242-1-PB.pdf

Triyono, K. (2007). Pengaruh Sistem Pengolahan Tanah dan Mulsa terhadap Konservasi Sumber
Daya Tanah. Jurnal Inovasi Pertanian, 6(1), 11-21. Retrieved from http://download.garuda.ristekdikti.go.id/articl e.php? article $=114908 \&$ val $=5262 \&$ title $=$ PEN GARUH SISTEM PENGOLAHAN TANAH DAN MULSA TERHADAP KONSERVASI SUMBER DAYA TANAH

Undang-Undang Nomor 18. (2012). Pangan. Undang-Undang Republik Indonesia. https:// doi.org/10.1002/bit.24773

Wahyuningtyas, R. (2010). Melestarikan Lahan dengan Olah Tanah Konservasi. Galam, 4(2), 81-96. Retrieved from http://foreibanjarbaru. or.id/wp-content/uploads/2012/1012/Hal 81 96.doc . 